\title{
Soft Power and Exchange Rate Volatility
}

\author{
Serhan Cevik (International Monetary Fund) ${ }^{1}$ \\ Richard Harris (University of Exeter) \\ Fatih Yilmaz (SLJ Macro Partners)
}

\begin{abstract}
Standard models - based exclusively on macro-financial variables - have made little progress in explaining the behavior of exchange rates. In this paper, we introduce a neglected set of "soft power" factors capturing a country's demographic, institutional, political and social underpinnings to shed some light on the "missing" determinants of exchange rate volatility over time and across countries. Based on a balanced panel dataset comprising 115 countries during the period 1996-2015, the empirical results are generally robust across different estimation methodologies and show a high degree of persistence in exchange rate volatility. After controlling for standard macroeconomic factors, we find that the "soft power" variables - such as an index of voice and accountability, life expectancy, educational attainments, fragility of the banking sector, financial openness, and the share of agriculture relative to services - have a statistically significant influence on the level of exchange rate volatility across countries. In other words, countries with greater "soft power" (i.e. better institutional quality) tend to experience a lower degree of exchange rate volatility.
\end{abstract}

\section{JEL Classification Numbers: C32; F33; G15}

Keywords: Exchange rate volatility, institutions

\footnotetext{
${ }^{1}$ Corresponding author: scevik@,imf.org; 202-623-6695; International Monetary Fund, 700 19th Street, NW, Washington, DC 20431.
} 


\section{INTRODUCTION}

Since the breakdown of the Bretton Woods system, major shifts in the global economy and financial markets have exacerbated the magnitude of exchange rate fluctuations. While Friedman (1953) famously argued that exchange rate volatility is a manifestation of macroeconomic volatility, empirical studies have uncovered a range of anomalies and puzzles that contradict the theoretical models of exchange rates. Meese and Rogoff (1983), for example, showed that there is no stable relationship between exchange rate fluctuations and fundamental factors, conflicting with the theoretical models predicting that exchange rate volatility can only increase when the variability of the underlying fundamentals increases. Exchange rate volatility is still of great interest to academics, policymakers, and market practitioners because the potential linkages between the behavior of exchange rates and other economic and financial variables.

The general consensus in the literature is that exchange rate volatility reflects a variety of global and country-specific factors, such as income growth, inflation, fiscal and current account balances, foreign exchange reserves, financial and trade openness, and the size and type of capital flows. It has also been shown that structural characteristics of the foreign exchange market such as the exchange rate regime and technical features such as order flows influence the extent of exchange rate volatility. Notwithstanding a cascade of follow-up papers, however, the findings of Meese and Rogoff (1983) remain unchallenged, with little progress in explaining - and predicting - exchange rate fluctuations with macroeconomic fundamentals. If exchange rates fluctuate beyond what is necessary to absorb real economic shocks, they become an autonomous source of shocks and instability. A significant share of exchange rate fluctuations is indeed shown to be explained by shocks originating in the foreign exchange market itself, due to movements in the exchange rate risk premium (Artis and Ehrmann, 2006; Farrant and Peersman, 2006).

The purpose of this paper is therefore to empirically shed some light on the "missing" crosscountry determinants of exchange rate volatility. Using a balanced panel comprising 115 countries from 1996 to 2015, we investigate the importance of "soft power" variables that encapsulate a country's demographic, institutional, political and social underpinnings that are generally ignored in the literature. ${ }^{2}$ In addition, we include a variety of control variables, drawn from the literature on exchange rate modeling, and which are expected to capture the conventional macro-financial determinants of exchange rate volatility. With regards to the "soft power" characteristics of individual countries, rather than relying on an arbitrary choice

\footnotetext{
${ }^{2}$ The concept of soft power-popularized by Nye (1990) in studying international relations — captures intangible resources beyond material considerations. Although the Institute for Government has developed an index of soft power for a limited set of countries over the period 2009-2012, it is difficult to quantify a multidimensional concept in a single indicator. Accordingly, in this paper, we focus on the underlying factors of "soft power" in a broad set of countries over a longer span of time.
} 
of a small set of variables, we take an 'agnostic' view and initially consider a wide range of demographic, institutional, political and social indicators. However, since there is inevitably a high degree of collinearity among the explanatory variables, we utilize a variable reduction technique that systematically eliminates those variables in the original set that are best explained by the remaining variables.

While there is no theoretical model linking "soft power" to exchange rate volatility, we consider the institutions-growth nexus - a widespread consensus in the literature - as a useful illustration of the linkages we have in mind between a country's "soft power" characteristics - underpinning its quality of institutions - and exchange rate fluctuations. Accordingly, we expect "soft power" factors to have a noticeable effect on exchange rate volatility - directly and indirectly_by enhancing complementarities between different kind of institutions, fostering better policy choices and shaping the pattern and evolution of macroeconomic fundamentals and risk premia. We present cross-country evidence that the volatility of exchange rates is significantly affected by "soft power" variables — such as an index of voice and accountability, life expectancy, educational attainments, fragility of the banking sector, financial openness, and the share of agriculture relative to services Our empirical analysis indicates that countries with greater "soft power" experience less exchange rate volatility. The results are robust to a number of important sensitivity checks, including different estimation approaches, sub-sample analysis and controlling for a host of conventional macroeconomic factors investigated in previous studies.

The remainder of this paper is organized as follows. Section II provides a brief overview of the literature. Section III explains how we estimate exchange rate volatility. Sections IV and $\mathrm{V}$ describe our empirical methodology and data sources, respectively. The econometric results are presented in Section VI, while we offer concluding remarks in Section VII.

\section{Literature OVERVIEW AND CONCEPTUAL FRAMEWORK}

The literature on exchange rates is vast, covering a wide range of theoretical and empirical strands. The volatility of exchange rates can have welfare costs through multiple channels, but mainly by increasing transaction costs and reducing the gains to international trade. A rich body of studies points out, albeit with mixed results, a negative effect of exchange rate volatility on investment, employment, growth, and international trade (Chowdhury, 1993; Federer, 1993; Dixit and Pindyck, 1994; Ramey and Ramey, 1995; Caballero and Pindyck, 1996; Obstfeld and Rogoff, 1998; Aizenman and Marion, 1999; Dell'Ariccia 1999; Bleaney and Greenway, 2001; Sauer and Bohara, 2001; Devereux and Engel, 2003; Rosenberg, 2004; Chong and Gradstein, 2009; Baum and Caglayan, 2010). This is likely to be a significant concern in emerging market economies, especially where large exchange rate misalignments contribute to the risks of sudden reversals of capital flows. 
With regards to the principal determinants of exchange rate volatility, the focus has been almost exclusively on macroeconomic fundamentals and structural characteristics of the foreign exchange market. Among the key findings in this literature is a positive link between real exchange rate volatility and the flexibility of nominal exchange rates (Mussa, 1986; Baxter and Stockman, 1989; Flood and Rose, 1995; Morales-Zumaquero and SosvillaRivero, 2010). The relationship between exchange rate volatility and economic openness, on the other hand, is less clear. While Hau (2002) and Bleaney (2008) show that more open economies tend to have lower exchange rate volatility, Amor (2008) finds the opposite result in the case of Asian countries. Bravo-Ortega and di Giovanni (2006), on the other hand, show that exchange rate volatility is negatively related to trade openness and per capita GDP and positively to trade taxes and a measure of remoteness (trade-weighted distance from the rest of the world), concluding that trade costs increase exchange rate volatility. The literature also suggests that productivity shocks play an important role in explaining real exchange rate fluctuations (Alexius, 2005). Beyond macroeconomic fundamentals, Lyons (2001) and Canales-Kriljenko and Habermeier (2004) show that structural characteristics and technical features of the foreign exchange market may influence the degree of exchange rate volatility.

There is no theoretical map linking measures of "soft power" to exchange rate volatility. ${ }^{3}$ There is, however, a bourgeoning literature on the institutions-growth nexus, laying out a conceptual framework that is relevant to the analysis of how "soft power" can influence the behavior of exchange rates (or other asset prices, for that matter). There is now widespread consensus among scholars and policymakers that institutions - generally defined as the economic, legal, political, and social organization of a country — are a fundamental determinant of cross-country differences in economic performance (North and Thomas, 1973; La Porta and others, 1997; Acemoglu, Johnson, and Robinson, 2001). Acemoglu and others (2003) expand this negative relationship to macroeconomic volatility, as measured by the volatility of the growth rate of output per worker, and demonstrate that macroeconomic policies have no predictive power after controlling for the impact of institutions. The institutions-growth nexus also helps to clarify the linkages between "soft power" characteristics - underpinning the quality and complementarity of different kinds of institutions - and exchange rate volatility.

The contribution of this paper is therefore to investigate the nature and scale of relationship between exchange rate volatility and institutional infrastructure and social features across countries. We expect to see "soft power" factors to have a prominent role in determining exchange rate volatility - directly and indirectly — by fostering better policy choices and shaping the pattern and evolution of macroeconomic fundamentals and risk premia.

\footnotetext{
${ }^{3}$ Phillips and others (2013) empirically link exchange rates to indicators of demographics, institutions and social policy in assessing current accounts, but this analysis does not attempt to explain exchange rate volatility.
} 


\section{Measuring Exchange Rate Volatility}

Rather than focusing exclusively on the behavior of bilateral exchange rates, we adopt an aggregate view of exchange rate volatility, using trade shares as weights to obtain the volatility of a country's effective exchange rate. It is also important to realize that the degree of exchange rate variability to which a country is exposed is not necessarily closely related to the type of exchange rate regime it has adopted. A country may peg its currency to an anchor currency (or a basket of currencies), but will float against all other currencies if the anchor currency does as well. Accordingly, since the choice between using the nominal effective exchange rate (NEER) and the real effective exchange rate (REER) is not likely to affect significantly measured volatility or the econometric results, we prefer the REER as the unit of measurement in this analysis.

We measure the annual volatility of the exchange rate as the natural logarithm of the realized variance of the trade-weighted REER return, computed using monthly returns. In particular, we define the volatility of the exchange rate for country $i$ in year $t$ as

(1) $\mathrm{VOL}_{i, t}=\ln \sum_{k=1}^{12} r_{i, t-1+k / 12}^{2}$

where $r_{i, t-1+k / 12}=\ln s_{i, t-1+k / 12}-\ln s_{i, t-1+(k-1) / 12}$ is the change in the natural logarithm of the REER for country $i$ between month $k-1$ and month $k$ of year $t-1$, and $s_{i, t-1+k / 12}$ is the exchange rate at the end of month $k$ of year $t$.

Figure 1 plots the realized standard deviation of REER returns over time, averaged across countries, both for the full sample (Panel A) and the developed and emerging market subsamples (Panel B). Exchange rate volatility declined from an average of 7.3 percent in the second half of the 1990s to 5.7 percent during the period 2000-07 before the global financial crisis of 2008, driven mainly by the moderation in emerging market economies. Furthermore, the difference between average exchange rate volatility between advanced and developing countries narrowed from the peak of 5.6 percentage points in 1998 to 1.1 percentage points in 2007. Although the global financial crisis resulted in a surge in exchange rate volatility to 8.6 percent in 2008, the behavior of trade-weighted REERs moderated towards the pre-crisis level by 2015 . However, there is substantial variation across countries and over time, with a minimum of 0.7 percent to a maximum of 82 percent during the period 1996-2015. 
Figure 1: Exchange Rate Volatility 1995-2015

Global Average

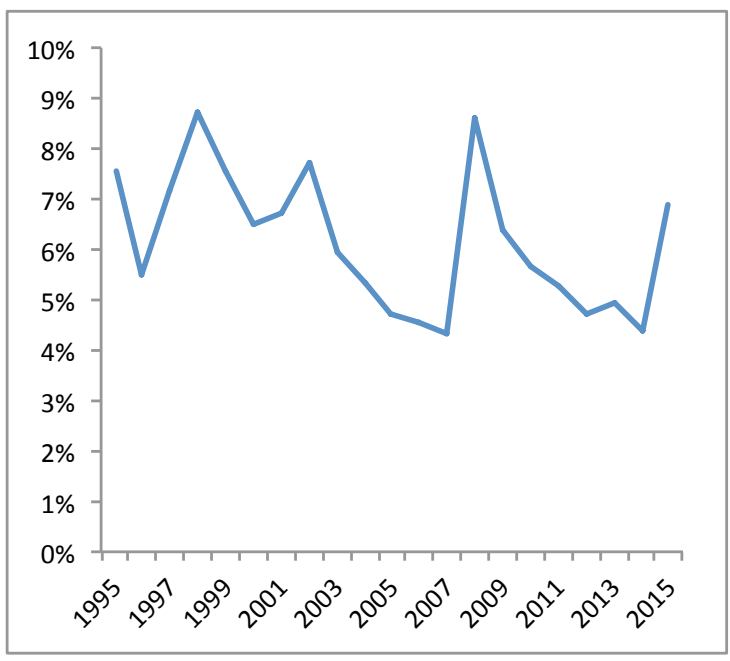

Sub-Sample Average

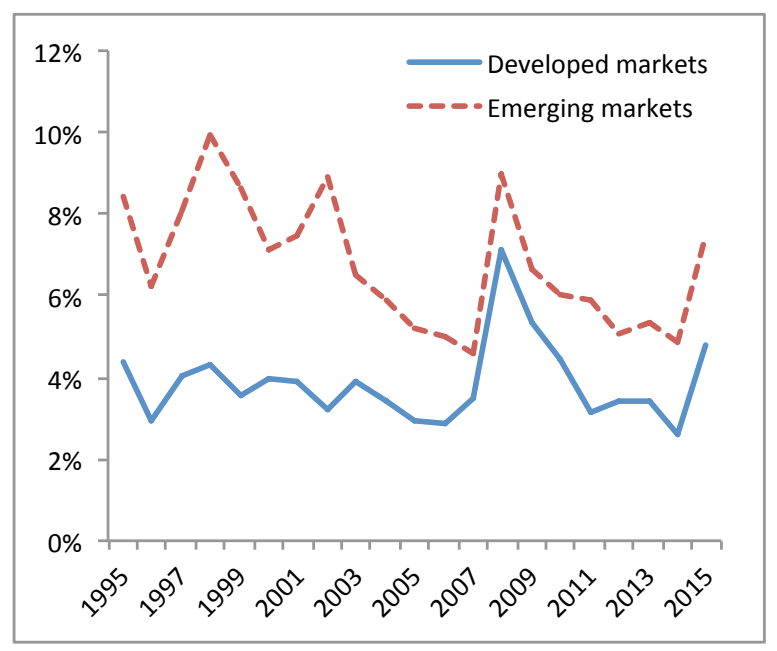

\section{ECONOMEtric Model ANd Estimation Methodology}

The "soft power" variables are more likely to have an impact on exchange rate volatility in the cross-section rather than the time series, and accordingly our starting point is a pooled regression that attempts to uncover this:

(2) $\mathrm{VOL}_{i, t}=\mu+\sum_{k=1}^{K} \alpha_{k} \mathrm{VOL}_{i, t-k}+\beta^{\prime} \mathbf{X}_{i, t}+\gamma^{\prime} \mathbf{Z}_{i, t}+\varepsilon_{i, t}$

where $\mathrm{VOL}_{i, t}$ is the volatility of the REER for country $i$ in year $t$, as defined in Section III, $\mathbf{X}_{i, t}$ is a $J \times 1$ vector of structural variables, $\mathbf{Z}_{i, t}$ is a $K \times 1$ vector of macroeconomic control variables and $\varepsilon_{i, t}$ is a random error, which we assume to be uncorrelated across time and countries. The dynamic nature of the model reflects the fact that it is well documented in the literature that at short horizons, the volatility of exchange rate returns is a highly persistent process. The degree of persistence in volatility decreases as the return horizon increases but, as we show below, it remains significant at the annual horizon used in this study. In the empirical analysis, we set $K=2$.

We begin the analysis by estimating the pooled model given by (2) using two approaches. In the first, we assume that all of the right hand side variables are strictly exogenous and use OLS. In the second, we assume that the control variables, $\mathbf{Z}_{i, t}$, are pre-determined and use the Instrumental Variables (IV) approach, with the first lag of the control variables used as instruments. In both cases, we report robust standard errors of the estimated coefficients. The model is estimated both for the full sample of 115 countries and the sub-sample of 90 developing countries and 25 advanced countries. 
To further explore the relationship between exchange rate volatility and the "soft power" variables, we consider a fixed effects version of the model:

(3) $\mathrm{VOL}_{i, t}=\mu_{i}+\sum_{k=1}^{K} \alpha_{k} \mathrm{VOL}_{i, t-k}+\beta^{\prime} \mathbf{X}_{i, t}+\gamma^{\prime} \mathbf{Z}_{i, t}+\varepsilon_{i, t}$

where $\mu_{i}$ is an unobserved country-specific effect. The presence of the country-specific effect in conjunction with the lagged dependent variable creates a bias in the usual least squares dummy variable estimator when the time dimension is fixed, since demeaning creates a correlation between the error term and the lagged dependent variable in the transformed model. We therefore estimate the model using the System Generalized Method of Moments (GMM) approach of Blundell and Bond (1998). This involves constructing two sets of equations, one with first differences of the endogenous and pre-determined variables instrumented by suitable lags of their own levels, and one with the levels of the endogenous and pre-determined variables instrumented with suitable lags of their own first differences. ${ }^{4}$ Strictly exogenous variables in the model enter the instrument matrix in the conventional way, i.e. in first differences or levels depending on the equation, with one column per instrument. The number of available instruments increases with the time period $t$ and so the model is estimated as a system of equations, with one equation for each period.

The System GMM approach yields consistent estimates of the model parameters while allowing for potential endogeneity in the regressors. We estimate two versions of the model given by Equation (3). In the first, we assume that the control variables, $\mathbf{Z}_{i, t}$, are strictly exogenous. In the second, we assume that they are endogenous. In both cases, we assume that the structural variables are strictly exogenous. We use one-step GMM and report robust standard errors. ${ }^{5}$ We also report the Hansen $J$ test of over-identifying restrictions for the joint validity of the instruments. As an additional test of the validity of the instruments, we report the Arellano and Bond (1998) test for second-order serial correlation in the error term of the first-difference equation. ${ }^{6}$

The use of all available lagged levels of the variables in the GMM estimation leads to a proliferation in the number of instruments. This reduces the efficiency of the estimator in finite samples, and potentially leads to over-fitting. This is a particular problem when the right hand side variables are assumed to be pre-determined or endogenous, since for these

\footnotetext{
${ }^{4}$ The use of the Difference GMM approach of Arellano and Bond (1991), which uses only the first difference equation, yields similar results but with reduced statistical significance for some variables.

${ }^{5}$ The use of the two-step GMM yields similar results but with reduced statistical significance for some variables.

${ }^{6}$ The error term in the first-difference equation is first order serially correlated by construction, but higher order serial correlation should be zero under the maintained assumption that the error term in Equation (3) is serially uncorrelated.
} 
variables, each time period contributes a separate vector to the instrument matrix. A further issue is that the use of a large number of instruments significantly weakens the Hansen $J$ test of over-identifying restrictions, and so the detection of over-identification is hardest when it is most needed. Conversely, however, restricting the instrument set too much results in a loss of information that leads to imprecisely estimated coefficients. Estimation of such models therefore involves a delicate balance between maximizing the information extracted from the data on the one hand, and guarding against over-identification on the other.

To establish the robustness of our results, therefore, we estimate various specifications of the model. First, only the one or two most recent lags of the available instruments are used in the GMM estimation. Second, the instruments are collapsed into a single vector, which reduces the number of moment conditions for a given number of instrument lags used. Third, the control variables are replaced by their significant principal components (i.e. those that have an associated eigenvalue greater than unity). We report the results obtained using different combinations of these restrictions.

\section{DATA}

Our objective in this paper is to empirically investigate the importance of "soft power" variables that encapsulate a country's demographic, institutional, political and social underpinnings that are generally ignored in the literature. Accordingly, we include a number of control variables, drawn from the literature on exchange rate modeling, and which are expected to capture the conventional macro-financial drivers of exchange rate volatility. With regards to the "soft power" factors, we take an 'agnostic' view and consider a wide range of demographic, institutional, political and social indicators. We expect these "soft power" characteristics such as governance and social conditions to have a significant effect on exchange rate volatility — directly and indirectly—by fostering better policy choices and shaping the pattern and evolution of macroeconomic fundamentals and risk premia.

The empirical analysis employs annual data for a broad panel of 115 countries, as well as the sub-samples of 25 advanced economies and 90 developing countries, over the period 19962015. ${ }^{7}$ We use the IMF's country classification system to label countries as "advanced" and "emerging and developing" according to (1) per capita income level, (2) export diversification - so natural resource exporters that tend to have high per capita GDP would not make the classification for advanced economy, and (3) degree of integration into the global financial system. The full list of countries is reported in Table A1 in the Appendix. The choice of sample represents a balance between data availability for individual countries

\footnotetext{
${ }^{7}$ Although we have a relatively short time dimension, the balanced panel used in this paper provides equal heterogeneity conditional distribution and thereby should yield more robust estimations than unbalanced panels generally exploited in the empirical literature.
} 
and a desire to have a large a sample as possible. In this section, we provide a detailed description of the variables used in the empirical analysis.

\section{Dependent Variable}

The volatility of each country's exchange rate, $\mathrm{VOL}_{i, t}$, is measured by the realized volatility of the REER, as described in Section III, constructed using monthly data drawn from the IMF's International Financial Statistics database.

\section{Control Variables}

We include 10 control variables, drawn from the literature on exchange rate modeling, and which are expected to capture the fundamental macroeconomic drivers of exchange rate volatility. The control variables are consumer price inflation, the volatility of the terms of trade, the volatility of labor productivity growth, the volatility of the ratio of government consumption to GDP, the ratio of the current account balance to GDP, trade openness, export concentration, the exchange rate regime, the ratio of credit to GDP, and stock market capitalization. These series are compiled from the IMF's International Financial Statistics and World Economic Outlook databases and the World Bank's World Development Indicators database. Panel B of Table A2 in the appendix gives the precise definitions of the control variables, their sources and expected signs.

\section{"Soft Power" Variables}

Rather than relying on an arbitrary choice of a small set of variables to capture the "soft power" characteristics of individual countries, we take an 'agnostic' view and initially consider a wide range of demographic, institutional, political and social indicators drawn from a number of different sources. In particular, we start with a universe of 20 variables, split into five broad categories:

Governance: Political stability, government effectiveness, regulatory quality, rule of law, control of corruption, and voice and accountability.

Population: Median age, total fertility rate, infant mortality rate, life expectancy, and child dependency.

Education: Average years of primary schooling, average years of secondary schooling, and average years of tertiary schooling.

Financial Sector: Bank z-score, bank concentration, and financial openness . 
Development: Real GDP per capita GDP, the share of agriculture in GDP, and the share of agriculture in GDP relative to the service sector.

The data for these variables are drawn from the World Bank's Governance Indicators database, the Polity IV Database, and the International Country Risk Guide. Panel A of Table A1 in the Appendix gives precise definitions of the 20 "soft power" variables, their sources and their expected signs with respect to exchange rate volatility.

There is inevitably a high degree of collinearity among the control and "soft power" variables, both among variables within the same category, and among variables in different categories. As is well known, while collinearity does not invalidate the estimation of the econometric model, it may complicate the interpretation of the estimated coefficients by inflating the associated standard errors, potentially making it difficult to distinguish the marginal effects of individual variables. In the sample, absolute pairwise correlations range from zero to close to unity. As might be expected, the highest correlations are between variables within the same category (for example, a correlation of 0.96 between government effectiveness and the rule of law), but there are also some high correlations between variables in different categories (for example, a correlation of 0.83 between real GDP per capita and control of corruption).

In the panel data model that we estimate, we allow for unobserved time fixed effects, and in some cases, also country fixed effects. This will tend to reduce collinearity since the pairwise correlation between any two variables arises partly from common year or country effects. For example, the correlation between government effectiveness and the rule of law falls from 0.96 to 0.46 once both variables are demeaned by year and by country. Nevertheless, in spite of the fact that the inclusion of year and country effects in the model will tend to reduce effective pairwise correlations, we mitigate the effects of potential collinearity among the predictor variables by using variable reduction, which eliminates those variables in the original set that are best explained by the remaining variables according to a statistical criterion.

The variable reduction technique that we employ is based on the variance inflation factor (VIF) of each variable $x_{i}$, which is given by

$$
V I F_{i}=\frac{1}{1-R_{i}^{2}}
$$

where $R_{i}^{2}$ is the coefficient of determination in a regression of $x_{i}$ on the remaining variables. The VIF measures the extent to which a variable can be explained by a linear combination of the remaining variables, and shows how much the variance of the estimated coefficient is increased as a result of collinearity (see, for example, Chatterjee and Hadi, 1986) 
We recursively estimate the VIF for each of the entire set of 20 "soft power" variables, each time dropping the variable that has the highest VIF. We continue until no variable has a VIF higher than 5.0. This yields a final set of nine "soft power" variables: political stability, voice and accountability, life expectancy, primary education, tertiary education, bank z-score, bank concentration, financial openness, and the share of agriculture in GDP relative to the service sector. The number of variables retained within each category in the full sample ranges from one (for the population category) to three (for the financial sector category).

We undertake two robustness checks to explore the sensitivity of the final model specification to the way in which the variable reduction procedure is implemented. First, we used an alternative - and more conservative - VIF threshold of 2.5, which yields six "soft power" variables. The lower VIF threshold inevitably reduces the number of retained variables, leading to a more parsimonious model with somewhat lower collinearity between the variables. However, all of the variables in both the governance and development categories are eliminated when the lower VIF threshold is employed. Second, we applied the variable reduction procedure after demeaning each variable by both country and year (i.e. after extracting fixed country and year effects). Owing to the lower pairwise correlations between the demeaned variables, fewer variables are dropped, but the qualitative conclusions that we draw are broadly similar. We report results only for the VIF cut-off of 5.0 applied to the 20 "soft power" variables without demeaning. ${ }^{8}$

The control variables generally have much lower pairwise correlations, both with each other, and with the control variables. For example, the highest correlation within the set of control variables is 0.56 (between the volatility of the terms of trade and export concentration), and the highest correlation between the control variables and the "soft power" variables is 0.51 (between median age and export concentration). As a check, we applied the variable reduction procedure described above to the combined set of 30 "soft power" and control variables. With a VIF threshold of 5.0, none of the control variables is eliminated. Even at the VIF threshold of 2.5, all of the control variables are retained. Moreover, the set of "soft power" variables that was retained (using either VIF threshold) was almost identical to when the control variables were excluded from the variable reduction procedure.

\section{EMPIRICAl RESUlts}

We begin the analysis by first reporting the results of the pooled panel model using the Ordinary Least Squares (OLS) method, in Table 1, for our full sample of 115 countries as well as the sub-samples of 25 developed and 90 emerging market economies over the period 1996-2015. We estimate both static and dynamic versions of the pooled OLS model. The results show that lagged exchange rate volatility in the dynamic model is statistically highly

\footnotetext{
${ }^{8}$ The results for the other cases are available on request.
} 
significant for all three sample groups, indicating a high degree of persistence in currency volatility over time. It should be noted that while its inclusion does not alter the sign of most of the other variables included in the analysis, it significantly lowers the magnitude of the other coefficients. Furthermore, the persistence of exchange rate volatility appears to be substantially greater in emerging market economies than in developed countries.

Turning first to the control variables, the pattern of coefficients is broadly as expected, but the magnitude and statistical significance of the relationship varies between advanced and emerging market economies. The estimated coefficient on consumer price inflation, which tends to capture macroeconomic stability, has the predicted positive sign, and with a greater magnitude in the case of advanced economies. Trade openness is a highly significant factor with a dampening effect on exchange rate volatility, while the volatility of both productivity growth and terms of trade appear to have an insignificant effect on (except in the case of developing countries where the volatility of terms of trade is found to contribute to greater exchange rate volatility). In line with previous research, the type of exchange rate regime is a significant determinant of exchange rate volatility, as greater flexibility leads to a higher level of currency volatility. The impact of exchange rate regime is present across all countries, but stronger in developing economies. Finally, measures of financial development (the ratio of credit to GDP and stock market capitalization) appear to have some positive effect on exchange rate volatility, except in the case of in developing countries.

The results obtained from the pooled panel estimation show that a number of "soft power" variables are statistically significant, highlighting the influence of intangible resources underpinned by demographic, institutional, political and social characteristics. In particular, we find that the index of voice and accountability and life expectancy have dampening effects on exchange rate volatility. Likewise, financial openness, the Z-score of banks, and the share of agriculture in GDP relative to the service sector lower the volatility of exchange rates. These findings remain broadly robust to the inclusion of lagged exchange rate volatility, as well as for the sub-samples of advanced and developing countries. Interestingly, the results show that primary schooling contributes to greater exchange rate volatility across all countries (but not statistically insignificant in the case of emerging markets), while tertiary educational attainments appear to have statistically significant, but with differing effects - increasing exchange rate volatility in advanced economies and lowering currency volatility in developing countries. ${ }^{9}$ The estimations based on the IV approach, presented in Table 2, are broadly similar in terms of the sign and magnitude of coefficients in the pooled panel data estimations, but yield different results in terms of statistical significance.

\footnotetext{
${ }^{9}$ Although human capital is inevitably measured with substantial error (Cohen and Soto, 2007), these findings remain robust if we use alternative measures of educational attainments, and indicate a nonlinear effect of human capital accumulation.
} 
The estimations based on the pooled panel model exclude unobserved country-specific effects. We therefore estimate a fixed-effects version of the dynamic model given by Equation (3) for the sample of 115 countries, using the System GMM technique, initially under the assumption that both the control and "soft power" variables are strictly exogenous. Table 3 presents the four specifications estimated using various combinations of instrument reduction. In specification (1), all available lags of the lagged dependent variable are used as GMM instruments, with each contributing a vector to the instrument matrix. The lagged exchange rate volatility remains highly significant, with a coefficient of 0.391 for $t-1$ and 0.157 for $t-2$, suggesting that volatility is highly persistent. A number of the control variables are significant, and with the expected signs. Of the "soft power" variables, voice and accountability, life expectancy, primary schooling, fragility of the banking sector as measured by the Z-score, and financial openness are highly significant across all specifications of the model, and all except primary education have the expected sign.

We investigate the robustness of the System GMM results by considering alternative specifications that reduce the instrument set by restricting the number of lags used as instruments to the most recent two (specification (2)), collapsing the instruments into a single vector (specification (3), and both (specification (4). These restrictions all lead to a reduction in the $p$-value of the Hansen $J$ test, and in the case of specifications (2) and (3), there is evidence that the instrument set is misspecified. However, specification (4), which uses 'only' 40 instruments (versus the 225 instruments used in the unrestricted case), appears to be reasonably well specified in terms of instrument choice. The estimation results for this specification (as well as for specifications (2) and (3)) are broadly similar to the unrestricted case. The notable difference is that the coefficient on lagged exchange rate volatility, while remaining statistically very significant, is somewhat lower in value, suggesting lower persistence. The remaining coefficients are generally similar, though larger in magnitude. The preliminary conclusion from Table 3 , under which it is assumed that both the control and "soft power" variables are strictly exogenous, is therefore that exchange rate volatility is negatively related to life expectancy, fragility of the banking sector and financial openness, and positively related to primary schooling.

With the aim of reducing the instrument set further, Table 4 repeats the estimation of Table 3 , but with the control variables replaced by their four significant principal components (i.e. those with an associated eigenvalue greater than one). All four specifications yield coefficient estimates on the "soft power" variables that are similar to those reported in Table 3 , with the exception that voice and accountability is now statistically significant. In all four cases, the third and fourth principal components are statistically significant at the one percent level, the second principal component is significant at the 10 percent level, while the first principal component is insignificant. Again, the first specification, in which the instrument set is unrestricted, gives no evidence of misspecification although this may be caused by the proliferation of instruments. This is confirmed by the fact that for the second specification, the null hypothesis of instrument validity is strongly rejected. However, the third and fourth 
specifications appear to be well specified. The estimated coefficients are similar to the coefficients for the corresponding specification in Table 3, and the overall conclusions, remain unchanged.

The analysis thus far has assumed that both the control and the "soft power" variables are strictly exogenous. However, feedback effects between exchange rate volatility and economic conditions would lead to a violation of this assumption. Table 5 therefore considers an alternative specification of the model in which the control variables, which largely capture macroeconomic determinants of exchange rate volatility, are assumed to be endogenous. This inevitably leads to a significant increase in the number of instruments that are available in the estimation of the model. To mitigate the effect of this, we continue to use the first four principal components of the control variables in place of the variables themselves. We consider three of the four specifications of the instrument set used in Tables 3 and 4. In particular, we omit the case where all available lags are used as instruments in their uncollapsed form since this yields an unfeasibly large instrument set. However, in addition to using the two most recent lags of the instruments, we also consider the case where only the single most recent lag is used, both uncollapsed and collapsed.

Using the two most recent lags of the instruments, uncollapsed, (specification (1)), the second, third and fourth principal components of the control variables are again significant, and have the same signs and similar magnitudes as in Table 4. The coefficients on lagged exchange rate volatility are highly significant, and the coefficients on the "soft power" variables are similar to the previous case. Very similar estimation results are obtained when just the single most recent lag used (specification (2)). But again, in both of these specifications, the inability of the Hansen $J$ test to reject the null hypothesis of instrument validity may be due to the number of instruments used. Indeed, when the instrument set is collapsed, which substantially reduces the total number of instruments, there is weak evidence of misspecification when either the full set of lags is used (specification (3)) or when only the two most recent lags are used (specification (4)). The estimated coefficients on the "soft power" variables and on lagged exchange rate volatility are largely unchanged, and the coefficients on the third, fourth and fifth principal components of the control variables remain statistically significant. Finally, using only the most recent lag of the instruments, collapsed into a single vector (specification (5)), the model appears to be well specified, and the coefficient estimates are similar to those obtained with the other specifications. However, the further reduction in the size of the instrument set is detrimental to the precision of the estimation leading to somewhat larger standard errors. Overall, the results from Table 5 suggest that allowing for endogeneity in the control variables does not significantly affect the estimated relationship between exchange rate volatility and the "soft power" variables. 


\section{CONCLUDing REMARKS}

A rich body of empirical research has identified a number of anomalies and puzzles that contradict the theoretical models of exchange rates and showed no robust relationship between exchange rate volatility and the variability of underlying macroeconomic fundamentals. As conventional empirical models have made little progress in explaining the behavior of exchange rates, in this paper we attempt to uncover the "missing" sources of exchange rate volatility by introducing a neglected set of factors. Using a balanced panel dataset comprising of 115 advanced and developing countries over the period 1996-2015, in addition to standard macroeconomic factors, we consider 20 "soft power" variables that encapsulate a country's demographic, institutional, political and social underpinnings.

The empirical results are generally robust across different estimation methodologies, as well as for the sub-samples of advanced and developing countries. First, we show that exchange rate volatility is highly persistent over time, especially in emerging market economies. Second, we find cross-country evidence that the level of exchange rate volatility is significantly influenced by "soft power" variables - such as an index of voice and accountability, life expectancy, educational attainments, financial openness, the Z-score of banks, and the share of agriculture relative to services. In particular, we find that countries with greater "soft power" experience less exchange rate volatility. Robustness checks reveal that the effect of "soft power" remains significant after controlling for a host of standard macroeconomic variables investigated in previous studies.

What is the link, for example, between life expectancy and exchange rate volatility? We reason that improvements in life expectancy - and education - foster human capital accumulation and thereby contribute to an atmosphere that is less conducive to financial volatility. Accordingly, the empirical analysis presented in this paper has a number of policy implications related to minimizing the distortionary effects of excessive exchange rate volatility. In line with the existing literature, we show that macroeconomic strength remains a crucial axis of exchange rate stability. Beyond the standard metrics, however, we find that countries with greater "soft power" (i.e. better institutional quality) tend to experience a lower degree of exchange rate volatility. Therefore, institutional and structural reforms would also help reduce exchange rate volatility. This paper, in our view, is as a first step and calls for further empirical and theoretical studies to unlock the interactions between quantitative measures of "soft power" and exchange rates. 


\section{Table 1. The Determinants of FX Volatility \\ Pooled Model (Ordinary Least Squares)}

The table reports the results of estimating the pooled panel data model given by Equation (2) over the period 1996-2015 using the Ordinary Least Squares method. Results are reported for the full sample of 115 countries, the sub-sample of 25 developed countries and the subsample of 90 emerging countries. Year dummies are included in the estimation but not reported. The table reports the estimated coefficients and robust standard errors. '***', '**' and ' $*$ ' denote significance at the 1 percent, 5 percent and 10 percent levels, respectively. The table also reports the number of observations and the adjusted R-squared.

\begin{tabular}{|c|c|c|c|c|c|c|}
\hline & & Static & & & Dynamic & \\
\hline & All & Developed & Emerging & All & Developed & Emerging \\
\hline Volatility $(t-1)$ & & & & $\begin{array}{c}0.439 * * * \\
(0.028)\end{array}$ & $\begin{array}{c}0.345^{* * *} \\
(0.054)\end{array}$ & $\begin{array}{c}0.403 * * * \\
(0.031)\end{array}$ \\
\hline Volatility $(t-2)$ & & & & $\begin{array}{c}0.200 * * * \\
(0.026)\end{array}$ & $\begin{array}{c}0.178 * * * \\
(0.056)\end{array}$ & $\begin{array}{c}0.158^{* * *} \\
(0.028)\end{array}$ \\
\hline Control variables & & & & & & \\
\hline Inflation & $\begin{array}{c}2.223 * * * \\
(0.347)\end{array}$ & $\begin{array}{c}4.668^{* * *} \\
(1.440)\end{array}$ & $\begin{array}{c}2.170^{* * *} \\
(0.309)\end{array}$ & $\begin{array}{c}1.270 * * * \\
(0.256)\end{array}$ & $\begin{array}{c}4.144 * * * \\
(1.564)\end{array}$ & $\begin{array}{c}1.361 * * * \\
(0.252)\end{array}$ \\
\hline Vol of productivity growth & $\begin{array}{c}0.817 \\
(0.815)\end{array}$ & $\begin{array}{c}2.305 \\
(2.313)\end{array}$ & $\begin{array}{c}0.787 \\
(0.680)\end{array}$ & $\begin{array}{l}-0.163 \\
(0.471)\end{array}$ & $\begin{array}{l}1.606 \\
(2.228)\end{array}$ & $\begin{array}{l}-0.080 \\
(0.457)\end{array}$ \\
\hline Vol of terms of trade & $\begin{array}{c}0.302 \\
(0.205)\end{array}$ & $\begin{array}{c}0.345 \\
(0.855)\end{array}$ & $\begin{array}{l}0.420^{*} \\
(0.218)\end{array}$ & $\begin{array}{l}-0.061 \\
(0.169)\end{array}$ & $\begin{array}{l}-0.079 \\
(0.791)\end{array}$ & $\begin{array}{c}0.040 \\
(0.178)\end{array}$ \\
\hline Vol of gov cons/GDP & $\begin{array}{c}0.212 \\
(1.925)\end{array}$ & $\begin{array}{l}-6.413 \\
(6.650)\end{array}$ & $\begin{array}{c}1.742 \\
(1.924)\end{array}$ & $\begin{array}{c}0.129 \\
(1.662)\end{array}$ & $\begin{array}{l}-2.544 \\
(6.398)\end{array}$ & $\begin{array}{c}0.938 \\
(1.697)\end{array}$ \\
\hline Current account/GDP & $\begin{array}{c}0.022 \\
(0.167)\end{array}$ & $\begin{array}{c}0.610 \\
(0.395)\end{array}$ & $\begin{array}{c}0.465^{* *} \\
(0.181)\end{array}$ & $\begin{array}{c}0.054 \\
(0.119)\end{array}$ & $\begin{array}{c}0.577 \\
(0.366)\end{array}$ & $\begin{array}{c}0.214 \\
(0.134)\end{array}$ \\
\hline Trade openness & $\begin{array}{c}-0.119 * * * \\
(0.024)\end{array}$ & $\begin{array}{c}-0.135^{* * *} \\
(0.040)\end{array}$ & $\begin{array}{c}-0.099 * * * \\
(0.033)\end{array}$ & $\begin{array}{c}-0.039 * * \\
(0.020)\end{array}$ & $\begin{array}{l}-0.071^{*} \\
(0.036)\end{array}$ & $\begin{array}{l}-0.046 \\
(0.028)\end{array}$ \\
\hline Export concentration index & $\begin{array}{c}0.296^{* * *} \\
(0.087)\end{array}$ & $\begin{array}{c}0.164 \\
(0.374)\end{array}$ & $\begin{array}{l}-0.012 \\
(0.095)\end{array}$ & $\begin{array}{c}0.171^{* *} \\
(0.075)\end{array}$ & $\begin{array}{c}0.089 \\
(0.335)\end{array}$ & $\begin{array}{c}0.064 \\
(0.082)\end{array}$ \\
\hline FX regime & $\begin{array}{c}0.229 * * * \\
(0.021)\end{array}$ & $\begin{array}{c}0.167 * * * \\
(0.055)\end{array}$ & $\begin{array}{c}0.298 * * * \\
(0.023)\end{array}$ & $\begin{array}{c}0.077 * * * \\
(0.019)\end{array}$ & $\begin{array}{c}0.115^{* *} \\
(0.047)\end{array}$ & $\begin{array}{c}0.118 * * * \\
(0.023)\end{array}$ \\
\hline
\end{tabular}




\begin{tabular}{|c|c|c|c|c|c|c|}
\hline Credit/GDP & $\begin{array}{c}0.022 \\
(0.041)\end{array}$ & $\begin{array}{c}0.307^{* * *} \\
(0.055)\end{array}$ & $\begin{array}{c}0.023 \\
(0.060)\end{array}$ & $\begin{array}{c}0.043 \\
(0.032)\end{array}$ & $\begin{array}{c}0.177 * * * \\
(0.051)\end{array}$ & $\begin{array}{c}0.062 \\
(0.053)\end{array}$ \\
\hline Stock market cap/GDP & $\begin{array}{c}0.096^{* * *} \\
(0.022)\end{array}$ & $\begin{array}{c}0.070 \\
(0.043)\end{array}$ & $\begin{array}{c}0.041 \\
(0.026)\end{array}$ & $\begin{array}{c}0.021 \\
(0.018)\end{array}$ & $\begin{array}{c}0.015 \\
(0.038)\end{array}$ & $\begin{array}{l}-0.003 \\
(0.023)\end{array}$ \\
\hline \multicolumn{7}{|l|}{ "Soft power" variables } \\
\hline Political stability & $\begin{array}{l}-0.025 \\
(0.021)\end{array}$ & $\begin{array}{c}0.331^{* * * *} \\
(0.066)\end{array}$ & $\begin{array}{l}-0.029 \\
(0.023)\end{array}$ & $\begin{array}{l}-0.019 \\
(0.017)\end{array}$ & $\begin{array}{c}0.145^{* *} \\
(0.057)\end{array}$ & $\begin{array}{l}-0.025 \\
(0.019)\end{array}$ \\
\hline Voice and accountability & $\begin{array}{c}-0.105 * * * \\
(0.024)\end{array}$ & $\begin{array}{c}-0.164 * * \\
(0.076)\end{array}$ & $\begin{array}{l}-0.037 \\
(0.024)\end{array}$ & $\begin{array}{l}-0.022 \\
(0.019)\end{array}$ & $\begin{array}{l}-0.067 \\
(0.075)\end{array}$ & $\begin{array}{l}-0.001 \\
(0.021)\end{array}$ \\
\hline Life expectancy & $\begin{array}{c}-0.015 * * * \\
(0.002)\end{array}$ & $\begin{array}{c}0.131 * * * \\
(0.018)\end{array}$ & $\begin{array}{c}-0.012 * * * \\
(0.002)\end{array}$ & $\begin{array}{c}-0.006^{* * *} \\
(0.002)\end{array}$ & $\begin{array}{c}0.071 * * * \\
(0.017)\end{array}$ & $\begin{array}{c}-0.006^{* * *} \\
(0.002)\end{array}$ \\
\hline Primary schooling & $\begin{array}{c}0.070^{* * *} \\
(0.010)\end{array}$ & $\begin{array}{c}0.089 * * * \\
(0.034)\end{array}$ & $\begin{array}{c}0.006 \\
(0.011)\end{array}$ & $\begin{array}{c}0.022 * * \\
(0.009)\end{array}$ & $\begin{array}{c}0.042 \\
(0.031)\end{array}$ & $\begin{array}{c}0.001 \\
(0.010)\end{array}$ \\
\hline Tertiary schooling & $\begin{array}{c}0.029 \\
(0.049)\end{array}$ & $\begin{array}{c}0.703 * * * \\
(0.085)\end{array}$ & $\begin{array}{c}-0.162 * * * \\
(0.053)\end{array}$ & $\begin{array}{c}0.001 \\
(0.039)\end{array}$ & $\begin{array}{c}0.348^{* * *} \\
(0.083)\end{array}$ & $\begin{array}{l}-0.083^{*} \\
(0.049)\end{array}$ \\
\hline Bank Z-score & $\begin{array}{c}-0.010 * * * \\
(0.002)\end{array}$ & $\begin{array}{l}-0.006^{*} \\
(0.003)\end{array}$ & $\begin{array}{c}-0.012 \text { *** } \\
(0.002)\end{array}$ & $\begin{array}{c}-0.003 * * \\
(0.001)\end{array}$ & $\begin{array}{l}-0.003 \\
(0.003)\end{array}$ & $\begin{array}{c}-0.005 * * * \\
(0.002)\end{array}$ \\
\hline Bank concentration & $\begin{array}{c}0.000 \\
(0.001)\end{array}$ & $\begin{array}{c}0.001 \\
(0.001)\end{array}$ & $\begin{array}{l}0.001 * \\
(0.001)\end{array}$ & $\begin{array}{l}-0.000 \\
(0.001)\end{array}$ & $\begin{array}{c}0.001 \\
(0.001)\end{array}$ & $\begin{array}{c}0.000 \\
(0.001)\end{array}$ \\
\hline Financial openness & $\begin{array}{c}-0.050 * * * \\
(0.009)\end{array}$ & $\begin{array}{l}-0.083^{*} \\
(0.045)\end{array}$ & $\begin{array}{c}-0.026^{* *} \\
(0.010)\end{array}$ & $\begin{array}{c}-0.023 * * * \\
(0.008)\end{array}$ & $\begin{array}{l}-0.021 \\
(0.045)\end{array}$ & $\begin{array}{l}-0.016^{*} \\
(0.009)\end{array}$ \\
\hline GDP agriculture minus services & $\begin{array}{l}-0.185^{*} \\
(0.100)\end{array}$ & $\begin{array}{l}-0.156 \\
(0.505)\end{array}$ & $\begin{array}{c}-0.510^{* * *} \\
(0.098)\end{array}$ & $\begin{array}{l}-0.127 \\
(0.078)\end{array}$ & $\begin{array}{l}-0.336 \\
(0.442)\end{array}$ & $\begin{array}{c}-0.273 * * * \\
(0.082)\end{array}$ \\
\hline Observations & 2070 & 450 & 1620 & 2070 & 450 & 1620 \\
\hline Adjusted R-squared & 0.398 & 0.682 & 0.389 & 0.611 & 0.750 & 0.554 \\
\hline
\end{tabular}




\section{Table 2. The Determinants of FX Volatility Pooled Model (Instrumental Variables)}

The table reports the results of estimating the pooled panel data model given by Equation (2) over the period 1996-2015 using the Instrumental Variable method. The control variables are assumed to be pre-determined and the first lags are used as instruments. Results are reported for the full sample of 115 countries, the sub-sample of 25 developed countries and the subsample of 90 emerging countries. Year dummies are included in the estimation but not reported. The table reports the estimated coefficients and robust standard errors. '***', '**' and ' $*$ ' denote significance at the 1 percent, 5 percent and 10 percent levels, respectively. The table also reports the number of observations and the adjusted R-squared.

\begin{tabular}{|c|c|c|c|c|c|c|}
\hline & & Static & & & Dynamic & \\
\hline & All & Developed & Emerging & All & Developed & Emerging \\
\hline Volatility $(t-1)$ & & & & $\begin{array}{c}0.476 * * * \\
(0.030)\end{array}$ & $\begin{array}{c}0.359 * * * \\
(0.054)\end{array}$ & $\begin{array}{c}0.448 * * * \\
(0.034)\end{array}$ \\
\hline Volatility $(t-2)$ & & & & $\begin{array}{c}0.206^{* * *} \\
(0.026)\end{array}$ & $\begin{array}{c}0.186^{* * *} \\
(0.055)\end{array}$ & $\begin{array}{c}0.171 * * * \\
(0.029)\end{array}$ \\
\hline Control variables & & & & & & \\
\hline Inflation & $\begin{array}{c}2.971 * * * \\
(0.420)\end{array}$ & $\begin{array}{c}3.459 \\
(4.937)\end{array}$ & $\begin{array}{c}2.856^{* * * *} \\
(0.382)\end{array}$ & $\begin{array}{c}0.393 \\
(0.314)\end{array}$ & $\begin{array}{l}-1.482 \\
(4.449)\end{array}$ & $\begin{array}{l}0.585^{*} \\
(0.325)\end{array}$ \\
\hline Vol of productivity growth & $\begin{array}{c}0.629 \\
(0.960)\end{array}$ & $\begin{array}{c}4.600 \\
(3.283)\end{array}$ & $\begin{array}{c}0.491 \\
(0.749)\end{array}$ & $\begin{array}{l}-0.421 \\
(0.496)\end{array}$ & $\begin{array}{c}1.271 \\
(3.039)\end{array}$ & $\begin{array}{l}-0.398 \\
(0.467)\end{array}$ \\
\hline Vol of terms of trade & $\begin{array}{c}0.602 * * \\
(0.247)\end{array}$ & $\begin{array}{c}0.726 \\
(0.971)\end{array}$ & $\begin{array}{c}0.769^{* * *} \\
(0.253)\end{array}$ & $\begin{array}{l}-0.006 \\
(0.209)\end{array}$ & $\begin{array}{c}-0.092 \\
(0.897)\end{array}$ & $\begin{array}{c}0.118 \\
(0.211)\end{array}$ \\
\hline Vol of gov cons/GDP & $\begin{array}{l}-0.927 \\
(2.337)\end{array}$ & $\begin{array}{l}-6.846 \\
(8.666)\end{array}$ & $\begin{array}{c}0.867 \\
(2.364)\end{array}$ & $\begin{array}{c}0.260 \\
(1.872)\end{array}$ & $\begin{array}{l}-2.051 \\
(8.375)\end{array}$ & $\begin{array}{c}1.143 \\
(1.891)\end{array}$ \\
\hline Current account/GDP & $\begin{array}{l}-0.220 \\
(0.199)\end{array}$ & $\begin{array}{c}0.277 \\
(0.734)\end{array}$ & $\begin{array}{c}0.333 \\
(0.223)\end{array}$ & $\begin{array}{l}-0.244^{*} \\
(0.139)\end{array}$ & $\begin{array}{c}-0.392 \\
(0.704)\end{array}$ & $\begin{array}{l}-0.098 \\
(0.161)\end{array}$ \\
\hline Trade openness & $\begin{array}{c}-0.115^{* * *} \\
(0.024)\end{array}$ & $\begin{array}{c}-0.130^{* *} \\
(0.052)\end{array}$ & $\begin{array}{c}-0.115^{* * *} \\
(0.034)\end{array}$ & $\begin{array}{l}-0.040^{*} \\
(0.021)\end{array}$ & $\begin{array}{l}-0.038 \\
(0.048)\end{array}$ & $\begin{array}{c}-0.069 * * \\
(0.029)\end{array}$ \\
\hline Export concentration index & $\begin{array}{c}0.285^{* * *} \\
(0.095)\end{array}$ & $\begin{array}{c}0.266 \\
(0.433)\end{array}$ & $\begin{array}{l}-0.044 \\
(0.104)\end{array}$ & $\begin{array}{c}0.222 * * * \\
(0.084)\end{array}$ & $\begin{array}{c}0.396 \\
(0.413)\end{array}$ & $\begin{array}{c}0.123 \\
(0.093)\end{array}$ \\
\hline FX regime & $\begin{array}{c}0.223 * * * \\
(0.023)\end{array}$ & $\begin{array}{c}0.170^{* * * *} \\
(0.062)\end{array}$ & $\begin{array}{c}0.280 * * * \\
(0.025)\end{array}$ & $\begin{array}{c}0.060 * * * \\
(0.020)\end{array}$ & $\begin{array}{c}0.067 \\
(0.063)\end{array}$ & $\begin{array}{c}0.082 * * * \\
(0.024)\end{array}$ \\
\hline Credit/GDP & $\begin{array}{c}0.070 \\
(0.044)\end{array}$ & $\begin{array}{c}0.306^{* * * *} \\
(0.058)\end{array}$ & $\begin{array}{l}0.113^{*} \\
(0.067)\end{array}$ & $\begin{array}{c}0.018 \\
(0.034)\end{array}$ & $\begin{array}{c}0.124 * * \\
(0.054)\end{array}$ & $\begin{array}{c}0.065 \\
(0.058)\end{array}$ \\
\hline
\end{tabular}


Stock market cap/GDP

"Soft power" variables

Political stability

Voice and accountability

Life expectancy

Primary schooling

Tertiary schooling

Bank Z-score

Bank concentration

Financial openness

GDP agriculture minus services

Observations

Adjusted R-squared

$$
\begin{array}{cccccc}
0.094 * * * & 0.057 & 0.024 & 0.027 & 0.031 & 0.002 \\
(0.024) & (0.054) & (0.029) & (0.021) & (0.052) & (0.026)
\end{array}
$$

$\begin{array}{cccccc}-0.013 & 0.338 * * * & -0.021 & -0.030 * & 0.153 * * * & -0.035 * \\ (0.021) & (0.065) & (0.022) & (0.018) & (0.056) & (0.020)\end{array}$

$\begin{array}{cccccc}-0.112 * * * & -0.141 * & -0.038 & -0.018 & -0.044 & 0.002 \\ (0.024) & (0.078) & (0.024) & (0.019) & (0.079) & (0.020)\end{array}$

$\begin{array}{cccccc}-0.015 * * * & 0.133 * * * & -0.012 * * * & -0.004 * * & 0.072 * * * & -0.004 * \\ (0.002) & (0.021) & (0.002) & (0.002) & (0.019) & (0.002)\end{array}$

$\begin{array}{cccccc}0.072 * * * & 0.084 * * & 0.007 & 0.023 * * * & 0.033 & 0.007 \\ (0.011) & (0.033) & (0.012) & (0.009) & (0.032) & (0.010)\end{array}$

$\begin{array}{cccccc}0.020 & 0.705 * * * & -0.164 * * * & 0.014 & 0.325 * * * & -0.055 \\ (0.048) & (0.086) & (0.053) & (0.041) & (0.084) & (0.051)\end{array}$

$\begin{array}{cccccc}-0.009 * * * & -0.005 & -0.011 * * * & -0.003 * * & -0.001 & -0.004 * * * \\ (0.002) & (0.003) & (0.002) & (0.001) & (0.003) & (0.002)\end{array}$

$\begin{array}{cccccc}0.000 & 0.001 & 0.002 * * & -0.000 & 0.001 & 0.000 \\ (0.001) & (0.001) & (0.001) & (0.001) & (0.001) & (0.001)\end{array}$

$\begin{array}{cccccc}-0.043 * * * & -0.070 & -0.017 * & -0.028 * * * & -0.027 & -0.020 * * \\ (0.010) & (0.053) & (0.010) & (0.008) & (0.049) & (0.009)\end{array}$

$\begin{array}{cccccc}-0.199 * & -0.252 & -0.516 * * * & -0.117 & -0.237 & -0.235^{* * *} \\ (0.104) & (0.627) & (0.103) & (0.077) & (0.532) & (0.081) \\ & & & & & \\ 2070 & 450 & 1620 & 2070 & 450 & 1620 \\ 0.387 & 0.680 & 0.377 & 0.598 & 0.734 & 0.539\end{array}$




\section{Table 3. The Determinants of FX Volatility \\ Fixed Effects Model (GMM) \\ Control Variables Assumed to be Strictly Exogenous}

The table reports the results of estimating the dynamic panel data model given by Equation (2) for the sample of 115 countries over the period 1996-2015 using one-step system GMM. The control variables and structural variables are assumed to be strictly exogenous. In specifications (1) and (3), all lags from 2 onwards are used as GMM instruments. In specifications (2) and (4), lags 2 and 3 are used as GMM instruments. In specifications (3) and (4), the GMM instruments are collapsed into a single column. Year dummies are included in the estimation but not reported. The table reports the estimated coefficients and robust standard errors. ' $* * *$ ', ' $* *$ ' and ' $*$ ' denote significance at the 1 percent, 5 percent and 10 percent levels, respectively. The Hansen $\mathrm{J}$ test tests the null hypothesis that the instruments are valid in the presence of overidentification. The AR2 test is the ArellanoBond test of the null hypothesis of no second order serial correlation in the errors of the first difference equation. The table also reports the number of observations and the number of instruments.

Lags used for GMM
Instruments collapsed

Volatility $(t-1)$

Volatility $(t-2)$

Control variables

Inflation

Vol of productivity growth

Vol of terms of trade

Vol of gov cons/GDP

Current account/GDP

Trade openness
(1)

(2)

$2,-$

No

$0.391 * * *$

(0.024)

$0.157^{* * *}$

$(0.029)$

$1.397 * * *$

(0.246)

$-0.024$

(0.755)

$-0.007$

(0.175)

0.156

(2.405)

0.047

(0.148)

$-0.051^{*}$

$(0.028)$
(3)

2,-

Yes

$0.358 * * *$

(0.034)

$0.127^{* * *}$

(0.026)

(0.034)

$1.494 * * *$

(0.258)

$1.485^{* * *}$

(0.277)

0.072

(0.846)

(0.850)

0.034

(0.191)

0.03

(0.188)

0.176

(2.504)

0.174

(2.494)

0.042

(0.167)

0.042

(0.166)

$-0.058^{*}$

(0.031)

-0.059 *

(0.031)
(4)

2, 3

Yes

$0.307 * * *$

(0.043)

$0.082 * *$

(0.033)

$1.620^{* * *}$

(0.299)

0.219

(0.979)

0.087

(0.212)

0.202

(2.643)

0.035

(0.194) 


\begin{tabular}{|c|c|c|c|c|}
\hline Export concentration index & $\begin{array}{c}0.188^{* * *} \\
(0.076)\end{array}$ & $\begin{array}{c}0.200 * * \\
(0.087)\end{array}$ & $\begin{array}{c}0.199^{* *} \\
(0.085)\end{array}$ & $\begin{array}{c}0.217 * * \\
(0.100)\end{array}$ \\
\hline FX regime & $\begin{array}{c}0.099 * * * \\
(0.025)\end{array}$ & $\begin{array}{c}0.116^{* * *} \\
(0.028)\end{array}$ & $\begin{array}{c}0.114 * * * \\
(0.028)\end{array}$ & $\begin{array}{c}0.137 * * * \\
(0.034)\end{array}$ \\
\hline Credit/GDP & $\begin{array}{c}0.039 \\
(0.048)\end{array}$ & $\begin{array}{c}0.036 \\
(0.055)\end{array}$ & $\begin{array}{c}0.037 \\
(0.054)\end{array}$ & $\begin{array}{c}0.032 \\
(0.063)\end{array}$ \\
\hline Stock market cap/GDP & $\begin{array}{c}0.031 \\
(0.026)\end{array}$ & $\begin{array}{c}0.040 \\
(0.030)\end{array}$ & $\begin{array}{c}0.039 \\
(0.030)\end{array}$ & $\begin{array}{c}0.050 \\
(0.035)\end{array}$ \\
\hline "Soft power" variables & & & & \\
\hline Political stability & $\begin{array}{l}-0.020 \\
(0.024)\end{array}$ & $\begin{array}{l}-0.021 \\
(0.027)\end{array}$ & $\begin{array}{l}-0.021 \\
(0.027)\end{array}$ & $\begin{array}{l}-0.021 \\
(0.031)\end{array}$ \\
\hline Voice and accountability & $\begin{array}{l}-0.034 \\
(0.027)\end{array}$ & $\begin{array}{l}-0.043 \\
(0.030)\end{array}$ & $\begin{array}{l}-0.042 \\
(0.029)\end{array}$ & $\begin{array}{l}-0.055 \\
(0.035)\end{array}$ \\
\hline Life expectancy & $\begin{array}{c}-0.007 * * * \\
(0.002)\end{array}$ & $\begin{array}{c}-0.008^{* * *} \\
(0.003)\end{array}$ & $\begin{array}{c}-0.008^{* * *} \\
(0.003)\end{array}$ & $\begin{array}{c}-0.009^{* * * *} \\
(0.003)\end{array}$ \\
\hline Primary schooling & $\begin{array}{c}0.029^{* *} \\
(0.012)\end{array}$ & $\begin{array}{c}0.034^{* *} \\
(0.014)\end{array}$ & $\begin{array}{c}0.033^{* *} \\
(0.014)\end{array}$ & $\begin{array}{c}0.041^{* *} \\
(0.016)\end{array}$ \\
\hline Tertiary schooling & $\begin{array}{c}0.006 \\
(0.073)\end{array}$ & $\begin{array}{c}0.009 \\
(0.082)\end{array}$ & $\begin{array}{c}0.009 \\
(0.081)\end{array}$ & $\begin{array}{c}0.014 \\
(0.094)\end{array}$ \\
\hline Bank Z-score & $\begin{array}{c}-0.004^{* *} \\
(0.002)\end{array}$ & $\begin{array}{c}-0.005^{* *} \\
(0.002)\end{array}$ & $\begin{array}{c}-0.005^{* *} \\
(0.002)\end{array}$ & $\begin{array}{c}-0.006^{* *} \\
(0.002)\end{array}$ \\
\hline Bank concentration & $\begin{array}{l}-0.000 \\
(0.001)\end{array}$ & $\begin{array}{l}-0.000 \\
(0.001)\end{array}$ & $\begin{array}{l}-0.000 \\
(0.001)\end{array}$ & $\begin{array}{l}-0.000 \\
(0.001)\end{array}$ \\
\hline Financial openness & $\begin{array}{c}-0.027 * * \\
(0.011)\end{array}$ & $\begin{array}{c}-0.030 * * \\
(0.012)\end{array}$ & $\begin{array}{c}-0.030^{* *} \\
(0.012)\end{array}$ & $\begin{array}{c}-0.034 * * \\
(0.014)\end{array}$ \\
\hline GDP agriculture minus services & $\begin{array}{l}-0.135 \\
(0.127)\end{array}$ & $\begin{array}{l}-0.141 \\
(0.144)\end{array}$ & $\begin{array}{c}-0.14 \\
(0.143)\end{array}$ & $\begin{array}{l}-0.149 \\
(0.168)\end{array}$ \\
\hline Observations & 2070 & 2070 & 2070 & 2070 \\
\hline Number of instruments & 225 & 89 & 56 & 40 \\
\hline Hansen $J$ test $p$-value & 1.000 & 0.014 & 0.055 & 0.481 \\
\hline AR2 test $p$-value & 0.304 & 0.815 & 0.724 & 0.224 \\
\hline
\end{tabular}




\section{Table 4. The Determinants of FX Volatility \\ Fixed Effects Model (GMM) \\ PCA Control Variables Assumed to be Strictly Exogenous}

The table reports the results of estimating the dynamic panel data model given by Equation (2) for the sample of 115 countries over the period 1996-2015 using one-step system GMM. The control variables are replaced by their first four principal components, and are assumed to be strictly exogenous. In specifications (1) and (3), all lags from 2 onwards are used as GMM instruments. In specifications (2) and (4), lags 2 and 3 are used as GMM instruments. In specifications (3) and (4), the GMM instruments are collapsed into a single column. Year dummies are included in the estimation but not reported. The table reports the estimated coefficients and robust standard errors. ' $* * *$ ', ' $* *$ ' and ' $*$ ' denote significance at the 1 percent, 5 percent and 10 percent levels, respectively. The Hansen $\mathrm{J}$ test tests the null hypothesis that the instruments are valid in the presence of overidentification. The AR2 test is the Arellano-Bond test of the null hypothesis of no second order serial correlation in the errors of the first difference equation. The table also reports the number of observations and the number of instruments.

Lags used for GMM
Instruments collapsed

Volatility $(t-1)$

Volatility $(t-2)$

Control variables

PC1

PC2

PC3

PC4

"Soft power" variables

Political stability

Voice and accountability
(1)

(2)

$2,-$

No

$0.410^{* * *}$

(0.024)

$0.143^{* * *}$

(0.030)

0.010

(0.013)

$-0.031^{*}$

(0.018)

$0.085^{* * *}$

$(0.026)$

$0.078^{* * *}$

(0.019)

$-0.011$

(0.024)

$-0.062 * *$
(3)

2,-

Yes

$0.378 * * *$

(0.033)

$0.114 * * *$

(0.028)

(0.034)

0.012

(0.015)

$-0.033^{*}$

(0.019)

$0.097^{* * *}$

(0.031)

$0.088^{* * *}$

(0.020)

$-0.012$

(0.028)

$-0.072 * *$

$-0.070^{* *}$
0.013

(0.014)

$-0.033^{*}$

(0.019)

$-0.035 *$

(0.021)

$0.095^{* * *}$

$0.106^{* * *}$

(0.031)

(0.035)

$0.086 * * *$

$0.095^{* * *}$

(0.019)

(0.021)

$-0.012$

$-0.014$

(0.027)

(0.030)

$-0.079 * *$ 


$\begin{array}{lcccc} & (0.027) & (0.029) & (0.029) & (0.033) \\ \text { Life expectancy } & -0.008^{* * *} & -0.009^{* * *} & -0.009^{* * *} & -0.010^{* * *} \\ & (0.002) & (0.003) & (0.003) & (0.003) \\ \text { Primary schooling } & & & 0.033^{* *} & 0.038^{* *} \\ & \left(0.029^{* *}\right. & 0.034^{* *} & (0.014) & (0.016) \\ \text { Tertiary schooling } & -0.017 & (0.015) & -0.015 \\ & (0.067) & -0.016 & -0.016 & (0.083) \\ \text { Bank Z-score } & -0.005^{* *} & -0.006^{* *} & -0.006^{* *} & -0.006^{* *} \\ & (0.002) & (0.002) & (0.002) & (0.002) \\ \text { Bank concentration } & -0.000 & -0.000 & -0.000 & -0.001 \\ & (0.001) & (0.001) & (0.001) & (0.001) \\ \text { Financial openness } & & & & -0.037^{* * *} \\ & -0.031^{* * *} & -0.034^{* * *} & -0.034^{* * *} & (0.014) \\ \text { GDP agriculture minus services } & (0.011) & (0.013) & (0.012) & -0.253 \\ & -0.237^{*} & -0.246^{*} & -0.244^{*} & (0.155) \\ \text { Observations } & (0.123) & (0.141) & (0.137) & 2070 \\ \text { Number of instruments } & & & 34 \\ \text { Hansen J test p-value } & 2070 & 2070 & 2070 & 0.769 \\ \text { AR2 test p-value } & 219 & 83 & 0.152 & 0.245\end{array}$




\section{Table 5. The Determinants of FX Volatility \\ Fixed Effects Model (GMM) \\ PCA Control Variables Assumed to be Endogenous}

The table reports the results of estimating the dynamic panel data model given by Equation (2) for the sample of 115 countries over the period 1996-2015 using one-step system GMM. The control variables are replaced by their first four principal components, and are assumed to be endogenous. In specifications (1) and (4), lags 2 and 3 are used as GMM instruments. In specifications (2) and (5), only lag 2 is used as a GMM instrument. In specification (3), all lags from 2 onwards are used as GMM instruments. In specifications (3), (4) and (5), the GMM instruments are collapsed into a single column. Year dummies are included in the estimation but not reported. The table reports the estimated coefficients and robust standard errors. ' $* * *$ ', '**' and ' $*$ ' denote significance at the 1 percent, 5 percent and 10 percent levels, respectively. The Hansen $\mathrm{J}$ test tests the null hypothesis that the instruments are valid in the presence of overidentification. The AR2 test is the Arellano-Bond test of the null hypothesis of no second order serial correlation in the errors of the first difference equation. The table also reports the number of observations and the number of instruments.

Lags used for GMM
Instruments collapsed

Volatility $(t-1)$

Volatility $(t-2)$

Control variables

PC1

PC2

PC3

PC4

"Soft power" variables

Political stability

Voice and accountability
(1)

(2)

2,3
No

$0.366^{* * *}$

(0.030)

$0.117^{* * *}$

(0.031)

$-0.002$

(0.025)

$-0.107 * * *$

(0.036)

$0.157^{* * *}$

(0.032)

$0.186^{* * *}$

(0.026)

0.057

(0.035)

$-0.168^{* * *}$
(3)

2,2
No

$0.324 * * *$

(0.032)

$0.082^{* *}$

(0.035)

$-0.024$

(0.030)

$-0.120 * * *$

(0.040)

$0.193^{* * *}$

(0.037)

$0.217 * * *$

(0.031)

0.068

(0.044)

$-0.212 * * *$
(4)

(5)

2, -
Yes

$0.337 * * *$

(0.033)

$0.091 * * *$

(0.027)

$0.079^{* *}$

$(0.286)$

$0.319 * * *$

$(0.042)$

0.436

(0.292)

0.208

$(0.286)$

$-0.097$

(0.100)

(0.032)

$-0.031$

(0.036)

$-0.112$

$-0.128 * * *$

$-0.151^{* * *}$

(0.069)

$0.164^{* * * *}$

$0.205 * * *$

$0.280^{* *}$

(0.036)

(0.038)

(0.123)

$0.216^{* * *}$

$0.223 * * *$

$0.287 * * *$

(0.033)

(0.043)

(0.073)

$0.069^{*} \quad 0.086^{*}$

0.119

(0.039)

(0.047)

(0.132) 


\begin{tabular}{|c|c|c|c|c|c|}
\hline & $(0.043)$ & $(0.054)$ & $(0.053)$ & $(0.061)$ & $(0.137)$ \\
\hline Life expectancy & $\begin{array}{c}-0.012 * * * \\
(0.003)\end{array}$ & $\begin{array}{c}-0.014 * * * \\
(0.004)\end{array}$ & $\begin{array}{c}-0.013^{* * *} \\
(0.004)\end{array}$ & $\begin{array}{c}-0.015 * * * \\
(0.004)\end{array}$ & $\begin{array}{c}-0.017 * * * \\
(0.006)\end{array}$ \\
\hline Primary schooling & $\begin{array}{c}0.038^{* *} \\
(0.018)\end{array}$ & $\begin{array}{c}0.045^{* *} \\
(0.021)\end{array}$ & $\begin{array}{c}0.042 * * \\
(0.020)\end{array}$ & $\begin{array}{c}0.046^{* *} \\
(0.023)\end{array}$ & $\begin{array}{c}0.034 \\
(0.041)\end{array}$ \\
\hline Tertiary schooling & $\begin{array}{l}-0.096 \\
(0.084)\end{array}$ & $\begin{array}{l}-0.119 \\
(0.097)\end{array}$ & $\begin{array}{l}-0.105 \\
(0.096)\end{array}$ & $\begin{array}{l}-0.123 \\
(0.104)\end{array}$ & $\begin{array}{l}-0.246 \\
(0.219)\end{array}$ \\
\hline Bank Z-score & $\begin{array}{l}-0.004 \\
(0.003)\end{array}$ & $\begin{array}{l}-0.005 \\
(0.003)\end{array}$ & $\begin{array}{l}-0.004 \\
(0.003)\end{array}$ & $\begin{array}{l}-0.004 \\
(0.003)\end{array}$ & $\begin{array}{l}-0.002 \\
(0.008)\end{array}$ \\
\hline Bank concentration & $\begin{array}{c}0.002 * * \\
(0.001)\end{array}$ & $\begin{array}{c}0.002 * * \\
(0.001)\end{array}$ & $\begin{array}{c}0.002 * * \\
(0.001)\end{array}$ & $\begin{array}{c}0.003 * * \\
(0.001)\end{array}$ & $\begin{array}{c}0.003 \\
(0.002)\end{array}$ \\
\hline Financial openness & $\begin{array}{c}-0.034 * * \\
(0.014)\end{array}$ & $\begin{array}{c}-0.038^{* *} \\
(0.016)\end{array}$ & $\begin{array}{c}-0.037 * * \\
(0.015)\end{array}$ & $\begin{array}{c}-0.038^{* *} \\
(0.017)\end{array}$ & $\begin{array}{l}-0.029 \\
(0.033)\end{array}$ \\
\hline GDP agriculture minus services & $\begin{array}{c}-0.522 * * * \\
(0.172)\end{array}$ & $\begin{array}{c}-0.556^{* * *} \\
(0.210)\end{array}$ & $\begin{array}{c}-0.596 * * * \\
(0.207)\end{array}$ & $\begin{array}{c}-0.613 * * * \\
(0.227)\end{array}$ & $\begin{array}{c}-0.633^{*} \\
(0.341)\end{array}$ \\
\hline Observations & 2070 & 2070 & 2070 & 2070 & 2070 \\
\hline Number of instruments & 287 & 202 & 126 & 42 & 37 \\
\hline Hansen $J$ test $p$-value & 1.000 & 1.000 & 0.570 & 0.090 & 0.329 \\
\hline AR2 test $p$-value & 0.967 & 0.410 & 0.438 & 0.105 & 0.733 \\
\hline
\end{tabular}




\section{Table A1. Sample of Countries}

The table reports the 115 countries that are used in the empirical analysis.

$\begin{array}{cc}\text { Algeria } & \text { Ecuador } \\ \text { Argentina } & \text { Egypt } \\ \text { Armenia } & \text { El Salvador } \\ \text { Australia } & \text { Estonia } \\ \text { Austria } & \text { Finland } \\ \text { Bahrain } & \text { France } \\ \text { Barbados } & \text { Gabon } \\ \text { Belgium } & \text { Germany } \\ \text { Belize } & \text { Ghana } \\ \text { Benin } & \text { Greece } \\ \text { Bolivia } & \text { Guatemala } \\ \text { Botswana } & \text { Guyana } \\ \text { Brazil } & \text { Haiti } \\ \text { Burundi } & \text { Honduras } \\ \text { Cambodia } & \text { Hungary } \\ \text { Cameroon } & \text { Iceland } \\ \text { Canada } & \text { India } \\ \text { Central African Rep. } & \text { Indonesia } \\ \text { Chile } & \text { Iran } \\ \text { China } & \text { Ireland } \\ \text { Hong Kong } & \text { Israel } \\ \text { Colombia } & \text { Italy } \\ \text { Congo } & \text { Jamaica } \\ \text { Costa Rica } & \text { Japan } \\ \text { Cote d'Ivoire } & \text { Jordan } \\ \text { Cyprus } & \text { Kazakhstan } \\ \text { Czech Republic } & \text { Kenya } \\ \text { Denmark } & \text { Korea } \\ \text { Dominican Republic } & \text { Kuwait }\end{array}$

Lao People's Dem. Rep.
Latvia
Lesotho
Libya
Lithuania
Luxembourg
Malawi
Malaysia
Maldives
Mali
Malta
Mauritius
Mexico
Moldova
Morocco
Mozambique
Namibia
Netherlands
New Zealand
Nicaragua
Niger
Norway
Pakistan
Panama
Papua New Guinea
Paraguay
Peru
Philippines
Poland
Mala

Portugal
Romania
Russian Federation
Saudi Arabia
Senegal
Sierra Leone
Singapore
South Africa
Spain
Sri Lanka
Swaziland
Sweden
Switzerland
Tanzania
Thailand
Togo
Trinidad and Tobago
Tunisia
Turkey
Uganda
Ukraine
United Arab Emirates
United Kingdom
Uruguay
Venezuela
Vietnam
Yemen




\section{Table A2. Variable Definitions}

The table reports the variables used in the empirical analysis, their definitions, sources and expected signs. Panel A reports details of the control variables, while Panel B reports details of the "soft power" variables.

\section{Panel A: Control Variables}

Variable
Inflation
Volatility of terms of trade
Volatility of labour
productivity growth
Volatility of gov con/GDP
Current account
balance/GDP
Trade openness
Export concentration index
FX regime
Credit/GDP

Stock market cap/GDP

\section{Variable}

\section{Governance variables}

Political stability

Government effectiveness

\section{Definition}

Annual growth of rate of country level CPI inflation

$5 y$ rolling standard deviation of annual country level terms of trade index growth $5 y$ rolling standard deviation of annual labour productivity growth for each country.

Productivity is calculated as real GDP divided by total employment

$5 y$ rolling standard deviation of annual government consumption to GDP ratio Annual current account balance to GDP ratio

Real exports plus real imports divided by real GDP

Concentration indices of merchandise exports and imports by country.

FX regime dummy condensed between 1 (fixed) and 3 (free float), based on the official IMF exchange rate classification The ratio of domestic credit provided by the banking sector to GDP

The ratio of stock market capitalization to GDP

Worldwide
Source

IMF

IMF

UNCTAD

UNCTAD

IMF

UNCTAD

UNCTAD

IMF

Worldwide

Governance

Indicators (World

Bank)

Expected sign

Governance

Indicators (World

Bank)

\section{Panel B: "Soft Power" Variables}

The likelihood of political instability and/or politically- motivated violence, including terrorism

The quality of public services, the quality of the civil service and the degree of its
Definition

Source

Worldwide

Governance

Indicators (World

Bank)

Worldwide

Governance
Expected sign

Negative

Negative 
Regulatory quality

Rule of law

Control of corruption

Voice \& accountability

\section{Population variables}

Median age

Total fertility

Infant mortality

Life expectancy

Child dependency ratio

\section{Education variables}

Primary schooling Secondary schooling Tertiary schooling

\section{Financial variables}

Z-score of banks

Bank concentration

Financial Openness independence from political pressures, the quality of policy formulation and

Indicators (World

Bank)

implementation, and the credibility of the government's commitment to such policies The ability of the government to formulate and implement sound policies and regulations that permit and promote private sector development

The extent to which agents have confidence in and abide by the rules of society, and in particular the quality of contract enforcement, property rights, the police, and the courts, as well as the likelihood of crime and violence The extent to which public power is exercised for private gain, including both petty and grand forms of corruption, as well as "capture" of the state by elites and private interests The extent to which a country's citizens are able to participate in selecting their government, as well as freedom of expression, freedom of association, and a free media

Median age of the total population

Number of children per woman

Infant mortality rate for both sexes combined

Life expectancy at birth for both sexes combined

Ratio of population aged $0-14$ per 100 population aged 15-64
Governance

Indicators (World

Bank)

Worldwide

Governance

Indicators (World

Bank)

Worldwide

Governance

Indicators (World

Bank)

Worldwide

Governance

Indicators (World

Bank)
Worldwide

Negative

Negative

Negative

Negative

UN World Pop Negative

Prospects

UN World Pop Positive

Prospects

UN World Pop Positive

Prospects

UN World Pop Negative

Prospects

UN World Pop Positive

Prospects
Average years of primary schooling, age 15+ World Bank

Average years of secondary schooling, age 15+ Average years of tertiary schooling, age 15+
World Bank

World Bank
Negative

Negative

Negative

(ROA+(equity/assets))/st. $\operatorname{dev}(\mathrm{ROA})$ where st. World Bank

Negative $\operatorname{dev}(\mathrm{ROA})$ is the standard deviation of ROA calculated from underlying bank-by-bank unconsolidated data from Bankscope).

Assets of three largest commercial banks as a

World Bank

Positive share of total commercial banking assets The Chinn-Ito index measuring a country's degree of capital account openness

http://web.pdx.edu/ i Negative to/Chinn- 
Ito_website.htm

Economic development variables

GDP per capita

$\%$ GDP agriculture - \%

GDP service sector

$\%$ GDP of agriculture
Real GDP divided by total population

$\%$ share of agricultural sector in total GDP minus \% share of service sector in total GDP

$\%$ share of agricultural sector in total GDP
UNCTAD

UNCTAD

UNCTAD
Negative

Positive

Positive 


\section{References}

Acemoglu, D., S. Johnson, and J. Robinson, 2001, "The Colonial Origins of Comparative Development," American Economic Review, Vol. 91, pp. 1369-1401.

Acemoglu, D., S. Johnson, J. Robinson, and Y. Thaicharoen, 2003, "Institutional Causes, Macroeconomic Symptoms: Volatility, Crises and Growth," Journal of Monetary Economics, Vol. 50, pp. 49-123.

Aizenman, J., and N. Marion, 1999, "Uncertainty and the Disappearance of International Credit," NBER Working Paper, No. 7389 (Cambridge, MA: National Bureau of Economic Research).

Alexius, A., 2005, "Productivity Shocks and Real Exchange Rates," Journal of Monetary Economics, Vol. 52, pp. 555-566.

Amor, T., 2008, "Financial Integration and Real Exchange Rate Volatility: Evidence from South and South East Asia," International Journal of Business and Management, Vol. 3, pp. 112-124.

Arellano, M., and S. Bond, 1991, "Some Tests of Specification for Panel Data: Monte Carlo Evidence and an Application to Employment Equations," Review of Economic Studies, Vol. 58, pp. 277-297.

Artis, M., and M. Ehrmann, 2006, "The Exchange Rate-A Shock Absorber or Source of Shocks? A Study of Four Open Economies," Journal of International Money and Finance, Vol. 25, pp. 874-893.

Baldacci, E., I. Petrova, N. Belhocine, G. Dobrescu, and S. Mazraani, 2011, “Assessing Fiscal Stress,” IMF Working Paper, No. 11/100 (Washington: International Monetary Fund).

Baum, C., and M. Caglayan, 2010, “On the Sensitivity of the Volume and Variability of Trade Flows,” Journal of International Money and Finance, Vol. 29, pp. 79-93.

Baxter, M., and A. Stockman, 1989, "Business Cycles and the Exchange Rate Regime: Some International Evidence," Journal of Monetary Economics, Vol. 23, pp. 377-400.

Bleaney, M., 2008, "Openness and Real Exchange Rate Volatility: In Search of an Explanation," Open Economies Review, Vol. 19, pp. 135-146.

Bleaney, M., and D. Greenway, 2001, "The Impact of Terms of Trade and Real Exchange Rate Volatility on Investment and Growth in Sub-Saharan Africa," Journal of Development Economics, Vol. 65, pp. 491-500. 
Blundell, R., and S. Bond, 1998, "Initial Conditions and Moment Restrictions in Dynamic Panel Data Models," Journal of Econometrics, Vol. 87, pp. 115-143.

Bollerslev, T., 1986, "Generalized Autoregressive Conditional Heteroskedasticity," Journal of Econometrics, Vol. 31, pp. 307-327.

Bravo-Ortega, C., and J. di Giovanni, 2006, "Remoteness and Real Exchange Rate Volatility," IMF Staff Papers, Vol. 53, pp. 115-132.

Brodsky, D., 1984, "Fixed Versus Flexible Exchange Rates and the Measurement of Exchange Rate Instability," Journal of International Economics, Vol.16, pp.295-306.

Caballero, R., and R. Pindyck, 1996, "Uncertainty, Investment and Industry Evolution," International Economic Review, Vol. 37, pp. 641-662.

Canales-Kriljenko, J., and K. Habermeier, 2004, "Structural Factors Affecting Exchange Rate Volatility: A Cross-Section Study,” IMF Working Paper, No. 04/147 (Washington, DC: International Monetary Fund).

Chatterjee, S., and A. Hadi. 1986, "Influential Observations, High Leverage Points, and Outliers in Linear Regression,” Statistical Science, Vol 1, pp. 379-393.

Chong, A., and M. Gradstein, 2009, "Volatility and Firm Growth," Journal of Economic Growth, Vol. 14, pp. 1-25.

Chowdhury, A., 1993, "Does Exchange Rate Volatility Depress Trade Flows? Evidence from ErrorCorrection Models," Review of Economics and Statistics, Vol. 75, pp. 700-706.

Cohen, D., and M. Soto, 2007, "Growth and Human Capital: Good Data, Good Results," Journal of Economic Growth, Vol. 12, pp. 51-76.

Dell'Ariccia, G., 1999, "Exchange Rate Fluctuations and Trade Flows: Evidence from the European Union,” IMF Staff Papers, Vol. 46, pp. 315-334.

Devereux, M., and C. Engel, 2003, "Monetary Policy in the Open Economy Revisited: Price Setting and Exchange Rate Flexibility," Review of Economic Studies, Vol. 70, pp. 765-783.

Dixit, A., and R. Pindyck, 1994, Investment Under Uncertainty (Princeton, NJ: Princeton University Press).

Farrant, K., and G. Peersman, 2006, "Is the Exchange Rate a Shock Absorber or a Source of Shocks? New Empirical Evidence," Journal of Money, Credit, and Banking, Vol. 38, pp. 939-961. 
Federer, J., 1993, “The Impact of Uncertainty on Aggregate Investment Spending,” Journal of Money, Credit and Banking, Vol. 25, pp. 30-48.

Flood, R., and A. Rose, 1995, "Fixing Exchange Rates: A Virtual Quest for Fundamentals," Journal of Monetary Economics, Vol. 36, pp. 3-37.

Flood, R., and A. Rose, 1999, "Understanding Exchange Rate Volatility without the Contrivance of Macroeconomics,” Economic Journal, Vol. 109, pp. 660-672.

Friedman, M., 1953, “The Case for Flexible Exchange Rates," in Essays in Positive Economics (Chicago: University of Chicago Press).

Harris, R., and E. Tzavalis, 1999, "Inference for Unit Roots in Dynamic Panels Where the Time Dimension Is Fixed," Journal of Econometrics, Vol. 91, pp. 201-226.

Hau, H., 2002, "Real Exchange Rate Volatility and Economic Openness: Theory and Evidence," Journal of Money, Credit and Banking, Vol. 34, pp. 611-630.

Im, K., M. Pesaran, and Y. Shin, 2003, “Testing for Unit Roots in Heterogeneous Panels,” Journal of Econometrics, Vol. 115, pp. 53-74.

Kenen, P., and D. Rodrik, 1986, "Measuring and Analyzing the Effects of Short-term Volatility in Real Exchange Rates," Review of Economics and Statistics, Vol. 68, pp. 311-315.

Laeven, L., and F. Valencia, 2008, “Systemic Banking Crises: A New Database," IMF Working Paper, No. 08/224 (Washington: International Monetary Fund).

La Porta, R., F. Lopez-de-Silanes, A. Shleifer, and R. Vishny, 1997, “Legal Determinants of External Finance,” Journal of Finance, Vol. 52, pp. 1131-1150.

Levy-Yeyati, E., and F. Sturzenegger, 2005, "Classifying Exchange Rate Regimes: Deeds vs. Words," European Economic Review, Vol. 49, pp. 1603-1635.

Lyons, R., 2001, The Microstructure Approach to Exchange Rates (Cambridge, Mass.: MIT Press).

Meese, R., and K. Rogoff, 1983, "Empirical Exchange Rate Models of the Seventies: Do They Fit Out of Sample?" Journal of International Economics, Vol. 14, pp. 3-24.

Morales-Zumaquero, A., and S. Sosvilla-Rivero, 2010, "Structural Breaks in Volatility: Evidence for the OECD and non-OECD Real Exchange Rates," Journal of International Money and Finance, Vol. 29, pp. 139-168. 
Mussa, M., 1986, "Nominal Exchange Rate Regimes and the Behavior of the Real Exchange Rates: Evidence and Implications," Carnegie-Rochester Conference Series on Public Policy, Vol. 25, pp. 117-214.

North, D., and R. Thomas, 1973, The Rise of the Western World: A New Economic History (New York: Cambridge University Press).

Nye, J., 1990, “Soft Power,” Foreign Policy, Vol. 80, pp. 153-171.

Obstfeld, M., and K. Rogoff, 1998, "Risk and Exchange Rates,” NBER Working Paper, No. 6694 (Cambridge, MA: National Bureau of Economic Research).

Phillips, S., L. Catão, L. Ricci, R. Bems, M. Das, J. Di Giovanni, D. Unsal, M. Castillo, J. Lee, J. Rodriguez, and M. Vargas, 2013, “The External Balance Assessment (EBA) Methodology,” IMF Working Paper, No. 13/272 (Washington: International Monetary Fund).

Polak, J., 1988, "The Choice of an Exchange Rate Regime" in Development Issues in the Current International Monetary System: Essays in Honor of Byanti Khoswaman, edited by D. Sutalaksana (Singapore: Addison Wesley).

Ramey, G. and V. Ramey, 1995, "Cross-Country Evidence on the Link Between Volatility and Growth," American Economic Review, Vol. 85, pp. 1138-1151.

Roodman, D., 2009, “A Note on the Theme of Too Many Instruments," Oxford Bulletin of Economics and Statistics, Vol. 71, pp. 135-158.

Rose, A., 1996, "Explaining Exchange Rate Volatility: An Empirical Analysis of the Holy Trinity of Monetary Independence, Fixed Exchange Rates, and Capital Mobility," Journal of International Money and Finance, Vol. 15, pp. 925-945.

Rose, A., 2000, "One Market, One Money: Estimating the Effect of Common Currencies on Trade," Economic Policy, Vol. 30, pp. 7-45.

Rosenberg, M., 2004, "Firm Risk, Investment, and Employment Growth," Journal of Economics and Finance, Vol. 28, pp. 164-285.

Sauer, C., and A. Bohara, 2001, "Exchange Rate Volatility and Exports: regional Differences between Developing and Industrialized Countries," Review of International Economics, Vol. 9, pp. 133-152. 